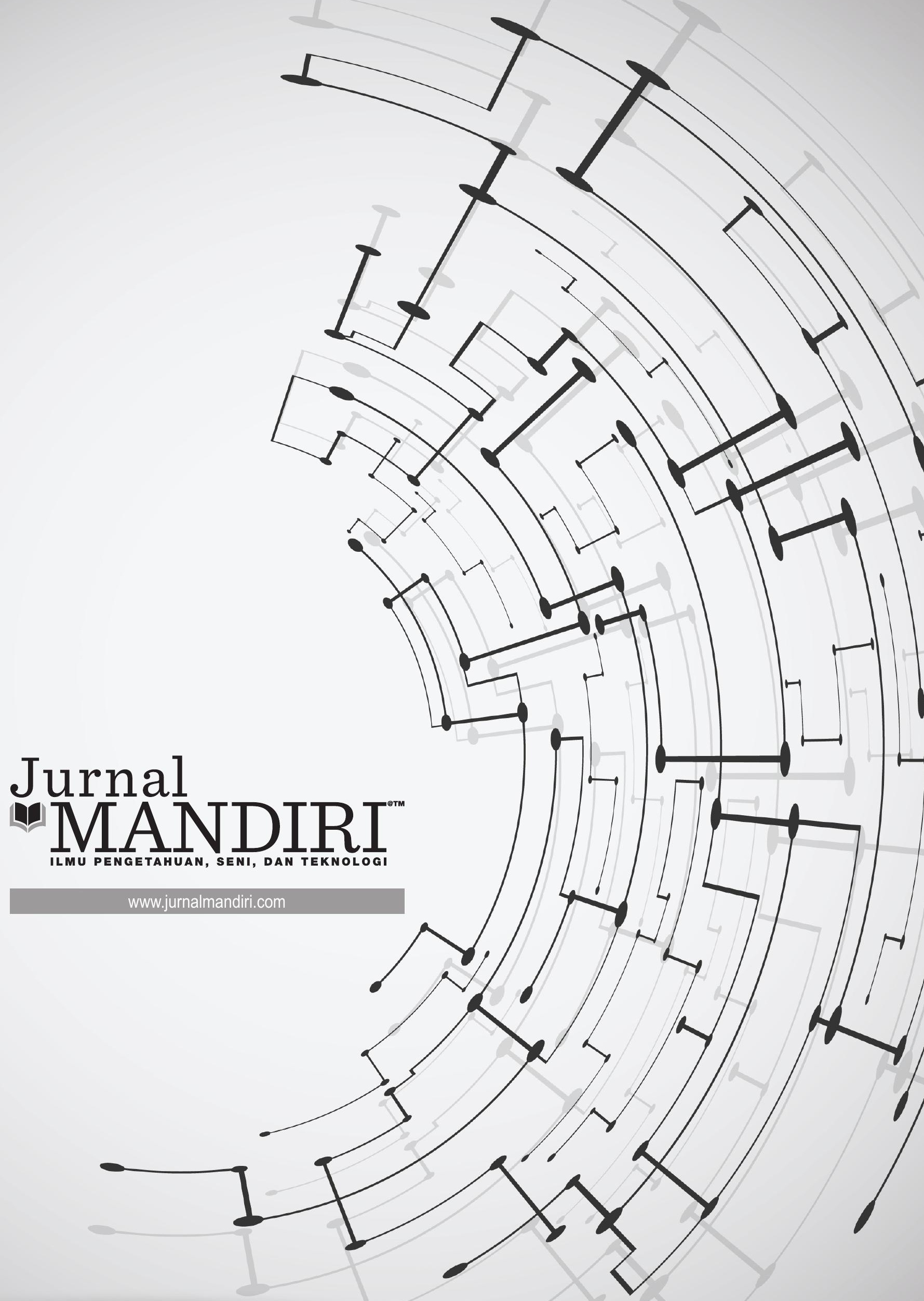


ISSN : 2580-3220, E-ISSN : 2580-4588

J. Mandiri., Vol. 3, No. 1, Juni 2019 (37 - 49)

(C)2018 Lembaga Kajian Demokrasi

dan Pemberdayaan Masyarakat (LKD-PM)

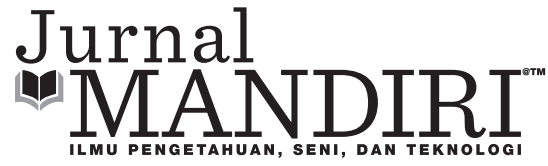

\title{
PENGARUH TUNJANGAN KINERJA DAN LINGKUNGAN KERJA TERHADAP MOTIVASI KERJA SERTA DAMPAKNYA TERHADAP KINERJA PEGAWAI PADA DIREKTORAT JENDERAL PENGELOLAAN HUTAN PRODUKSI LESTARI KEMENTERIAN LINGKUNGAN HIDUP DAN KEHUTANAN
}

\author{
Santi Octavianti \\ Fakultas Ekonomi, Universitas Pamulang \\ octavia_s99@yahoo.com
}

\begin{abstract}
Abstrak
Penelitian dimaksudkan untuk menguji Pengaruh Tunjangan Kinerja Dan Lingkungan Kerja terhadap Motivasi Kerja serta Dampaknya terhadap Kinerja Pegawai (Pada Direktorat Jenderal Pengelolaan Hutan Produksi Lestari Kementerian Lingkungan Hidup dan Kehutanan). Hal yang dapat memotivasi semangat kerja seseorang adalah untuk memenuhi kebutuhan serta kepuasan sebagai imbalan atau balas jasa dari jasa yang diberikannya kepada organisasi. Dengan adanya tunjangan kinerja yang memadai dan lingkungan kerja yang ergonomis sehingga terbentuk kondisi yang efektif, aman, sehat, nyaman dan efisien, maka pegawai akan termotivasi dan dengan motivasi kerja yang tinggi maka kinerja pegawai akan berjalan sesuai dengan tujuan yang diharapkan. Penelitian dilakukan dengan menggunakan metode kuantitatif deskriptif. pada bulan September 2016. Sampel berjumlah 177 responden. Metode pengumpulan data menggunakan kuesioner. Teknik analisis yang digunakan adalah path analysis (diagram jalur). Hasil penelitian dapat disimpulkan sebagai berikut: (1) tunjangan kinerja dan lingkungan kerja berpengaruh secara simultan dan signifikan terhadap motivasi kerja karena nilai $F_{\text {hitung }}$ lebih besar dari $F_{\text {tabel }}$ yaitu 18,028 > 3,05 (2) tunjangan kinerja berpengaruh secara signifikan terhadap motivasi kerja karena nilai $t_{\text {hitung }}$ lebih besar dari $t_{\text {tabel }}$ yaitu 3,565 > 1,974. (3) lingkungan kerja berpengaruh secara signifikan terhadap motivasi kerja karena nilai $t_{\text {hitung }}$ lebih besar dari $t_{\text {tabel }}$ yaitu 3,315 > 1,974. (4) tunjangan kinerja, lingkungan kerja dan motivasi kerja berpengaruh secara signifikan dan simultan terhadap kinerja karena nilai $F_{\text {hitung }}$ lebih besar dari $F_{\text {tabel }}$ yaitu 77.818> 3,05 (5) tunjangan kinerja mempunyai berpengaruh secara signifikan terhadap kinerja karena nilai $t_{\text {hitung }}$ lebih besar dari $t_{\text {tabel }}$ yaitu 4,229 > 1,974. (6) lingkungan kerja berpengaruh secara signifikan terhadap motivasi kerja karena nilai $t_{\text {hitung }}$ lebih besar dari $t_{\text {tabel }}$ yaitu 1,638 > 1,97. (7) motivasi kerja berpengaruh secara signifikan terhadap kinerja karena nilai $t_{\text {hitung }}$ lebih besar dari $t_{\text {tabel }}$ yaitu $12.161>1,974$.
\end{abstract}

Kata Kunci : Tunjangan Kinerja, Lingkungan Kerja, Motivasi Kerja, Kinerja

\section{Abstract}

The study was intended to examine the effect of performance and work environment benefits on work motivation and its impact on employee performance (at the Directorate General of Sustainable Production Forest Management of the Ministry of Environment and Forestry). The thing that can motivate someone's 
enthusiasm is to fulfill their needs and satisfaction as a reward or remuneration for the services they provide to the organization. With the existence of adequate performance allowances and an ergonomic work environment so that conditions that are effective, safe, healthy, comfortable and efficient are formed, the employee will be motivated and with high work motivation, the employee's performance will run according to the expected goals. The study was conducted using quantitative descriptive methods. in September 2016. The sample was 177 respondents. Methods of collecting data using a questionnaire. The analysis technique used is path analysis. The results of the study can be summarized as follows: (1) performance and work environment benefits simultaneously and significantly affect work motivation because the value of $F_{\text {count }}$ is greater than $F_{\text {table }}$ which is $18.028>3.05$ (2) performance allowances significantly influence work motivation because of the $t_{\text {count }}$ greater than $t_{\text {table }}$ which is $3.565>1.974$. (3) the work environment has a significant effect on work motivation because the $t_{\text {count }}$ is greater than $t_{\text {table }}$ namely 3.315> 1.974. (4) performance allowances, work environment and work motivation have a significant and simultaneous effect on performance because the value of $F_{\text {count }}$ is greater than $F_{\text {table }}$ which is $77.818>3.05$ (5) performance allowances have a significant effect on performance because the $t_{\text {count }}$ is greater than $t_{\text {table }}$ i.e. 4,229>1,974. (6) the work environment has a significant effect on work motivation because the $t_{\text {count }}$ is greater than $t_{\text {table }}$ which is $1.638>1.97$. (7) work motivation has a significant effect on performance because the $t_{\text {count }}$ is greater than $t_{\text {table }}$ ie $12.161>1.974$.

Keywords : Performance Allowance, Work Environment, Work Motivation, Performance

\section{PENDAHULUAN}

\section{Latar Belakang}

Pada dasarnya setiap perusahaan atau organisasi memiliki harapan untuk berkembang dan mencapai tujuannya. Keberadaan suatu perusahaan atau organisasi tidak terlepas dari unsur sumber daya manusia. Sumber daya yang dimaksud adalah orang-orang yang memberikan tenaga, pikiran, bakat, kreativitas, dan usahanya pada perusahaan. Setiap perusahaan berupaya untuk mendapatkan pegawai yang dapat memberikan suatu pencapaian target yang telah ditetapkan organisasi sebelumnya. Sumber daya manusia yang berkualitas merupakan aset terpenting bagi organisasi, karena perannya sebagai pelaksana kebijakan dan yang dapat menjalankan kegiatan operasional organisasi tersebut. Untuk mencapai visi dan misi dan agar bisa sukses dan terus maju, maka kunci sukses dari Kementerian Lingkungan Hidup dan Kehutanan (Kementerian LHK) dalam hal ini Direktorat Jenderal Pengelolaan Hutan Produksi Lestari (Ditjen PHPL) terletak bukan hanya ada pada keuangan dan teknologi tapi pada faktor manusianya juga.

Untuk dapat meningkatkan kinerja pegawai dengan optimal, maka Ditjen PHPL memberikan perhatian pada peningkatan kemampuan pegawai, memotivasi pegawai sehingga mendorong pegawai untuk melaksanakan tugasnya dengan baik dengan memberikan kompensasi yang sesuai dan menciptakan lingkungan kerja yag memberikan kenyamanan. Kinerja pegawai merupakan faktor yang harus mendapat perhatian utama dari setiap pimpinan organisasi termasuk Ditjen PHPL Kementerian Lingkungan Hidup dan Kehutanan karena kinerja pegawai tersebut akan menentukan tercapai atau tidaknya tujuan dari organisasi tersebut. Kinerja pegawai antara lain dipengaruhi oleh kompensasi (tunjangan kinerja), lingkungan kerja dan motivasi kerja.

Tunjangan Kinerja adalah penghasilan selain gaji yang diberikan kepada pegawai yang aktif berdasarkan kompetensi dan kinerja, yang merupakan fungsi dari keberhasilan pelaksanaan reformasi birokrasi atas dasar kinerja yang telah dicapai oleh seorang individu pegawai yang sejalan dengan kinerja yang hendak dicapai oleh instansinya. Besaran tunjangan kinerja yang diterima ditentukan berdasarkan kelas jabatannya sesuai dengan peraturan perundang-undangan yang berlaku.

Lingkungan kerja adalah keseluruhan alat perkakas dan bahan yang dihadapi, lingkungan sekitarnya dimana seseorang bekerja, metode 
kerjanya, serta pengaturan kerjanya baik sebagai perseorangan maupun sebagai kelompok. Lingkungan kerja dapat menciptakan hubungan kerja yang mengikat antara orang-orang yang ada di dalam lingkungannya. Oleh karena itu hendaknya diusahakan agar lingkungan kerja harus baik dan kondusif sehingga pegawai merasa betah berada di ruangan dan merasa senang serta bersemangat untuk melaksanakan tugas-tugasnya. Faktanya lingkungan kerja di Kementerian Lingkungan Hidup dan Kehutanan masih belum bisa sepenuhnya dikatakan baik dan kondusif.

Motivasi merupakan teknik penting yang digunakan untuk memelihara prestasi dan kepuasan kerja pegawai. Motivasi kerja adalah kumpulan proses psikologis yang menyebabkan pergerakan, arahan, dan kegigihan dari sikap sukarela yang mengarah pada tujuan. Motivasi kerja sangat diperlukan untuk memunculkan perilaku bekerja. Hal yang dapat memotivasi semangat kerja seseorang adalah untuk memenuhi kebutuhan serta kepuasan baik materiil maupun non materiil yang diperolehnya sebagai imbalan atau balas jasa dari jasa yang diberikannya kepada organisasi. Bila kompensasi materiil dan non materiil yang diterimanya semakin memuaskan, maka semangat bekerja seseorang, komitmen, dan prestasi kerja pegawai semakin meningkat.

Kinerja Pegawai adalah prestasi/kemampuan kerja yang diperlihatkan oleh seorang pegawai Kementerian Kehutanan dalam melaksanakan tugas dan fungsinya. Apabila seorang aparat pemerintahan mempunyai motivasi kerja yang tinggi maka akan berdampak positif pada kinerja pegawai tersebut. Maksudnya dengan motivasi kerja dan yang tinggi maka kinerja pegawai akan berjalan sesuai dengan tujuan yang diharapkan. Kenyataannya di Ditjen PHPL tidak semua hasil pekerjaan sesuai dengan hasil yang diinginkan dan target yang ditentukan. Masih terdapat beberapa pekerjaan yang kualitasnya masih kurang sesuai dengan yang diinginkan atau masih terdapat beberapa kecerobohan yang tentu saja sebagai manusia, pegawai Ditjen PHPL terkadang melalukan kesalahan. Ditjen PHPL telah membuat rencana kerja yang sesuai dengan renstra yang telah disusun dimana penataan rencana kerja diharapkan sesuai dengan hasil kerja dan tepat waktu dalam penyelesaiannya.

Berdasarkan uraian di atas, maka penulis tertarik untuk melakukan penelitian dengan judul "Pengaruh Tunjangan Kinerja dan Lingkungan Kerja terhadap Motivasi Kerja serta Dampaknya terhadap Kinerja Pegawai Pada Ditjen Pengelolaan Hutan Produksi Lestari Kementerian Lingkungan Hidup dan Kehutanan".

\section{Pembatasan Masalah}

Berdasarkan latar belakang dan identifikasi permasalahan maka penulis perlu membatasi permasalahan dalam penelitian ini. Hal ini disebabkan karena keterbatasan penulis dalam hal ruang dan waktu. Adapun batasan dari masalah dalam objek penelitian ini adalah tunjangan kinerja, lingkungan kerja, motivasi kerja, dan kinerja pegawai pada Direktorat Jenderal Pengelolaan Hutan Produksi Lestari Kementerian Lingkungan Hidup dan Kehutanan.

1. Penelitian dilakukan di Ditjen Pengelolaan Hutan Produksi Lestari Kementerian Lingkungan Hidup dan Kehutanan.

2. Tunjangan Kinerja adalah penghasilan selain gaji yang diberikan kepada pegawai yang aktif berdasarkan kompetensi dan kinerja, yang merupakan fungsi dari keberhasilan pelaksanaan reformasi birokrasi atas dasar kinerja yang telah dicapai oleh seorang individu pegawai yang sejalan dengan kinerja yang hendak dicapai oleh instansinya.

3. Lingkungan kerja adalah keseluruhan alat perkakas dan bahan yang dihadapi, ling kungan sekitarnya dimana seseorang bekerja, metode kerjanya, serta pengaturan kerjanya baik sebagai perseorangan maupun sebagai kelompok.

4. Motivasi kerja adalah kumpulan proses psikologis yang menyebabkan pergerakan, arahan, dan kegigihan dari sikap sukarela yang mengarah pada tujuan

5. Kinerja Pegawai adalah prestasi/kemampuan kerja yang diperlihatkan oleh seorang pegawai Kementerian Kehutanan dalam melaksanakan tugas dan fungsinya. 


\section{METODE}

\section{Tempat dan Waktu Penelitian}

Penelitian dilakukan di Direktorat Jenderal Pengelolaan Hutan Produksi Lestari, Kementerian Lingkungan Hidup dan Kehutanan.

Waktu Penelitian dilaksanakan pada bulan Maret-Nopember 2016. Rangkaian penelitian ini meliputi tiga tahap yaitu :

1 Pertama, persiapan penelitian yang meliputi penelitian pendahuluan, penyusunan proposal, pengurusan perizinan penelitian, dan ujian proposal.

2 Kedua, pelaksanaan penelitian yang meliputi menjaring data, tabulasi data, analisis data, dan pengecekan data.

3 Ketiga, akhir penelitian yang meliputi penyusunan laporan penelitian, pemeriksaan, penyusunan final, penyajian laporan/ujian tesis, dan perbaikan laporan

\section{Populasi}

Riduwan (2013:55) menyatakan bahwa populasi merupakan objek atau subjek yang berada pada suatu wilayah dan memenuhi syarat-syarat tertentu berkaitan dengan masalah penelitian. Populasi dalam penelitian ini adalah seluruh pegawai Ditjen PHPL berjumlah 319 orang.

Sampel yang diambil sebanyak 177 orang dari jumlah pegawai Ditjen PHPL Kementerian Lingkungan Hidup dan Kehutanan sejumlah 319 orang. Teknik pengambilan sampel ini dengan probabilitas sampling dengan menggunakan simple random sampling. Sampel diambil dari populasi secara acak atau tidak beraturan, sehingga semua anggota populasi mendapatkan peluang yang sama untuk menjadi anggota sampel.

\section{HASIL dan PEMBAHASAN \\ Hasil}

1. Uji Validitas

Dari seluruh tabel uji validitas memperlihatkan nilai $\mathrm{r}_{\text {hitung }}$ lebih besar dari nilai $\mathrm{r}_{\text {tabel }}$. Dengan demikian variabel tunjangan kinerja, lingkungan kerja, motivasi kerja dan kinerja dinyatakan valid untuk digunakan sebagai alat ukur variabel.

2. Uji Reliabilitas

\begin{tabular}{|l|c|c|c|}
\hline \multicolumn{4}{|c|}{ Tabel 3.1. Hasil Pengujian Reliabilitas } \\
\hline \multicolumn{1}{|c|}{ VARIABEL } & $\begin{array}{c}\text { CHRONBATH } \\
\text { ALPHA }\end{array}$ & $\begin{array}{c}\text { STANDART } \\
\text { RELIABILITAS }\end{array}$ & KESIMPULAN \\
\hline Tunjangan Kinerja $\left(\mathrm{X}_{1}\right)$ & 0,940 & 0,60 & Reliabel \\
\hline Lingkungan Kerja $\left(\mathrm{X}_{2}\right)$ & 0,877 & 0,60 & Reliabel \\
\hline Motivasi Kerja $(\mathrm{Y})$ & 0,892 & 0,60 & Reliabel \\
\hline Kinerja $(\mathrm{Z})$ & 0,923 & 0,60 & Reliabel \\
\hline \multicolumn{4}{|c}{ Sumber: Hasil output SPSS data primer yang telah diolah, September 2016 } \\
\hline
\end{tabular}

Hasil uji reliabilitas tersebut menunjukkan bahwa semua variabel mempunyai nilai Cronbach's Alpha lebih besar dari 0,60 sehingga dapat dikatakan semua konsep pengukur masing-masing variabel dari kuesioner adalah reliabel yang berarti bahwa kuesioner yang digunakan dalam penelitian ini merupakan kuesioner yang handal.

3. Uji Normalitas

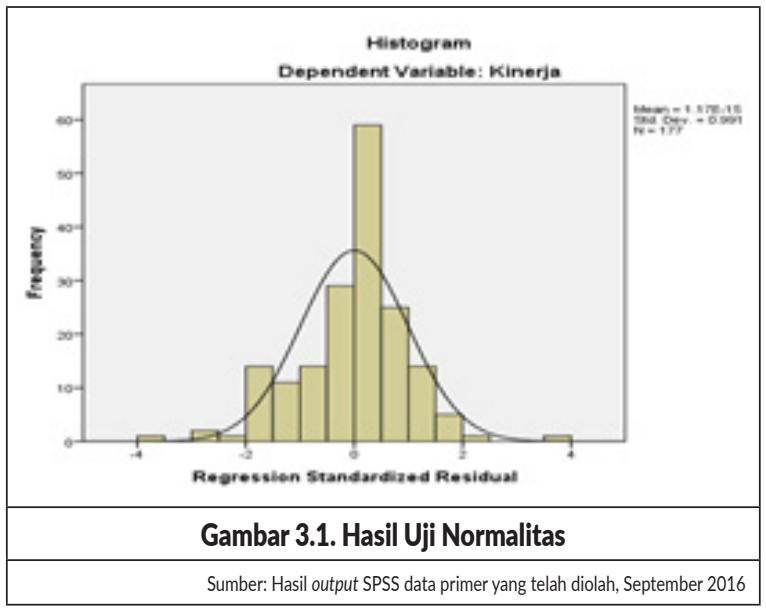

Dengan melihat tampilan grafik histogram di atas, maka dapat disimpulkan bahwa model regresi berdistribusi normal.

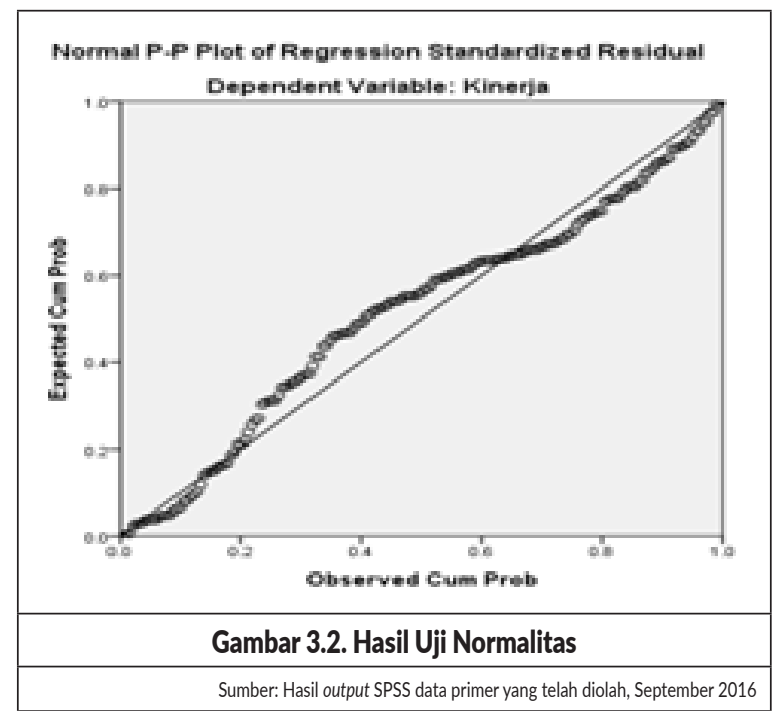


Dengan melihat kurva diatas, , maka model regresi memenuhi asumsi normalitas. Dari kedua grafik/kurva ini menunjukkan bahwa model regresi sesuai asumsi normalitas dan layak digunakan.

4. Uji Heteroskedastisitas

\begin{tabular}{|c|c|c|c|c|c|c|}
\hline \multicolumn{7}{|c|}{ Tabel 3.2. Hasil Uji Heteroskedastisitas } \\
\hline \multicolumn{7}{|c|}{ Correlations } \\
\hline & & & $\begin{array}{l}\text { ABS } \\
\text { RES }\end{array}$ & $\begin{array}{c}\text { Tunjangan } \\
\text { Kinerja }\end{array}$ & $\begin{array}{l}\text { Ling- } \\
\text { kun- } \\
\text { gan } \\
\text { Kerja }\end{array}$ & $\begin{array}{c}\text { Motivasi } \\
\text { Kerja }\end{array}$ \\
\hline & & & (K) & (E) & (K) & (E) \\
\hline \multirow[t]{3}{*}{ Spearman's rho } & \multirow{3}{*}{ ABS_RES } & $\begin{array}{l}\text { Correlation } \\
\text { Coefficient }\end{array}$ & 1.000 & -041 & -138 & -054 \\
\hline & & Sig. (2-tailed) & & .591 & .068 & .477 \\
\hline & & $\mathrm{N}$ & 177 & 177 & 177 & 177 \\
\hline
\end{tabular}

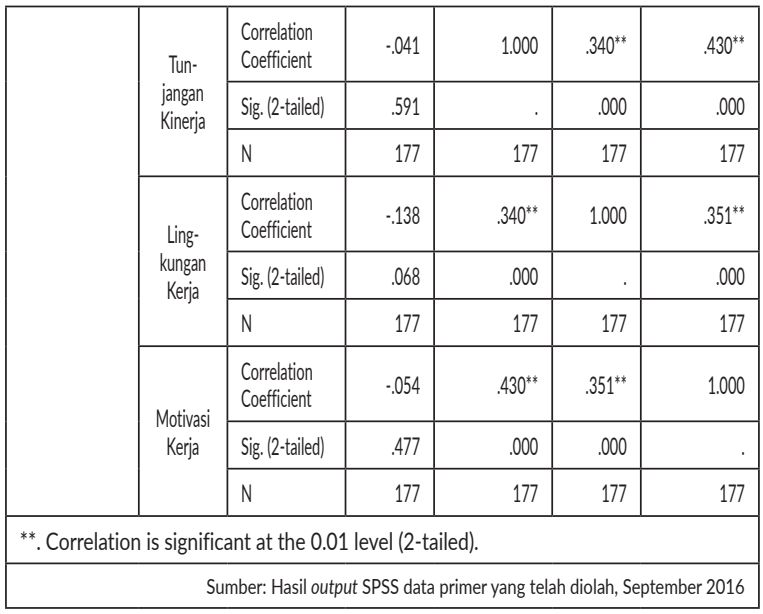

Berdasar pada tabel diatas, diketahui bahwa korelasi ketiga variabel independen dengan Absolut residual (ABS_RES) nilai signifikasnsinya lebih dari 0,05 , sehingga dapat disimpulkan bahwa pada model regresi tidak ada masalah heterokedastisitas.

5. Uji Multikolinearitas

\begin{tabular}{|c|c|c|c|c|c|c|c|c|}
\hline \multicolumn{9}{|c|}{ Tabel 3.3 Hasil Uji Multikolinearitas } \\
\hline \multicolumn{9}{|c|}{ Coefficients $^{\mathrm{a}}$} \\
\hline \multirow{2}{*}{\multicolumn{2}{|c|}{ Model }} & \multicolumn{2}{|c|}{$\begin{array}{l}\text { Unstandardized } \\
\text { Coefficients }\end{array}$} & \multirow{2}{*}{$\begin{array}{l}\text { Standardized } \\
\text { Coefficients } \\
\text { Beta }\end{array}$} & \multirow[b]{2}{*}{$t$} & \multirow[b]{2}{*}{ Sig. } & \multicolumn{2}{|c|}{ Collinearity Statistics } \\
\hline & & B & $\begin{array}{l}\text { Std. } \\
\text { Error }\end{array}$ & & & & Tolerance & VIF \\
\hline \multirow[t]{4}{*}{1} & (Constant) & 7.186 & 3.417 & & 2.103 & .037 & & \\
\hline & $\begin{array}{l}\text { Tunjangan } \\
\text { Kinerja }\end{array}$ & 144 & .039 & .201 & 3.683 & .000 & .822 & 1.216 \\
\hline & $\begin{array}{l}\text { Lingkungan } \\
\text { kerja }\end{array}$ & .076 & .047 & . 089 & 1.638 & .103 & .830 & 1.205 \\
\hline & Motivasi Kerja & .795 & .069 & .624 & 11.451 & .000 & .828 & 1.207 \\
\hline
\end{tabular}

Dari kedua tabel data, maka dapat ditarik kesimpulan bahwa dari kedua model regresi tidak terjadi multikolinearitas.

6. Path Analysis (Analisa Jalur)

Kerangka hubungan kausal empiris antara jalur dapat dibuat melalui struktur sebagai berikut:
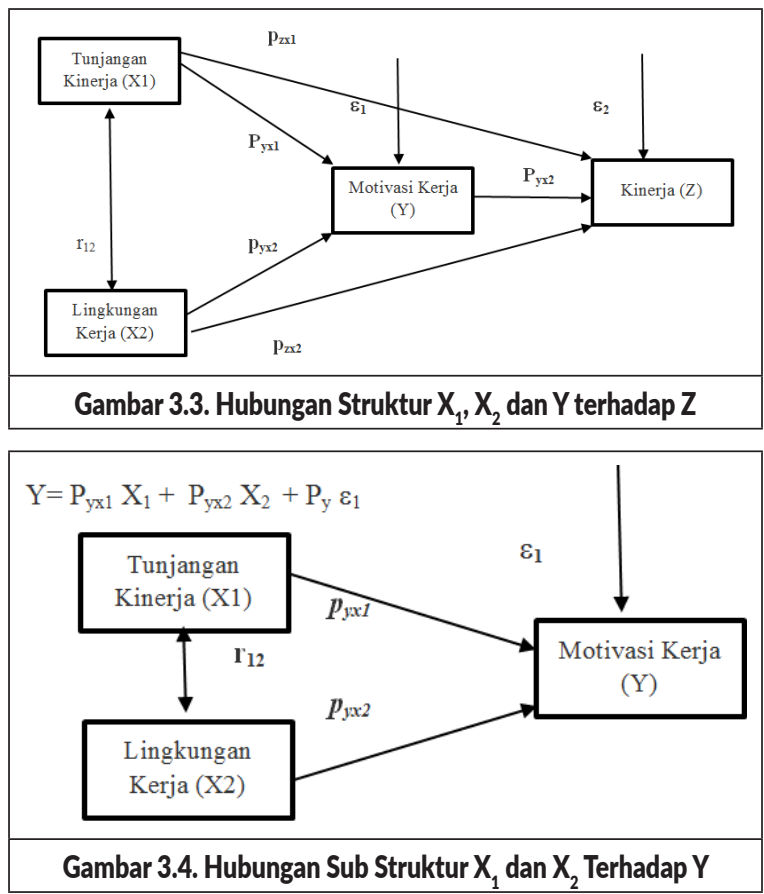

a. Menguji Sub-Struktur 1

$$
\mathrm{Y}=\mathrm{P}_{\mathrm{yx} 1} \mathrm{X}_{1}+\mathrm{P}_{\mathrm{yx} 2} \mathrm{X}_{2}+\mathrm{P}_{\mathrm{y}} \varepsilon_{1}
$$

Tabel.3.4. Anova Model 1- Sub-Struktur 1Tunjangan Kinerja $\left(\mathrm{X}_{1}\right)$ dan Lingkungan Kerja $\left(\mathrm{X}_{2}\right)$ Terhadap Motivasi Kerja $(\mathrm{Y})$

\begin{tabular}{|c|l|r|r|r|r|c|}
\hline \multicolumn{2}{|l|}{ Model } & $\begin{array}{c}\text { Sum of } \\
\text { Squares }\end{array}$ & df & $\begin{array}{c}\text { Mean } \\
\text { Square }\end{array}$ & F & Sig. \\
\hline 1 & Regression & 736.702 & 2 & 368.351 & 18.028 & $.000^{\mathrm{b}}$ \\
\hline & Residual & 3555.275 & 174 & 20.433 & & \\
\hline & Total & 4291.977 & 176 & & & \\
\hline $\begin{array}{l}\text { a. Dependent Variable: Motivasi Kerja } \\
\text { b. Predictors: (Constant), Lingkungan Kerja, Tunjangan Kinerja }\end{array}$ \\
\hline \multicolumn{7}{|c|}{ Sumber: Hasil output SPSS data primer yang diolah, September 2016 } \\
\hline
\end{tabular}

Tabel 3.5. Coefficients Model 1Sub-Struktur $1 \mathrm{X}_{1}$ dan $\mathrm{X}_{2}$ terhadap $\mathrm{Y}$

\begin{tabular}{|l|r|r|r|r|r|}
\hline \multicolumn{1}{|c|}{ Coefficients $^{\mathrm{a}}$} \\
\hline \multirow{2}{*}{ Model } & \multicolumn{1}{|c|}{$\begin{array}{c}\text { Unstandardized } \\
\text { Coefficients }\end{array}$} & \multicolumn{2}{|c|}{ Standardized Coefficients } \\
\cline { 2 - 7 } 1 (Constant) & \multicolumn{1}{c|}{ B } & \multicolumn{1}{c|}{ Std. Error } & \multicolumn{1}{c|}{ Beta } & \multicolumn{1}{c|}{$\mathrm{t}$} & \multicolumn{1}{c|}{ Sig. } \\
\hline Tunjangan Kinerja & .147 & .041 & .262 & 3.565 & .000 \\
\hline Lingkungan Kerja & .163 & .049 & .244 & 3.315 & .001 \\
\hline a. Dependent Variable: Motivasi Kerja & & & 10.123 & .000 \\
\hline \multicolumn{7}{|c|}{ Sumber: Hasil output SPSS data primer yang diolah, September 2016} \\
\hline
\end{tabular}




\begin{tabular}{|c|c|c|c|c|c|c|c|c|c|}
\hline \multicolumn{10}{|c|}{$\begin{array}{l}\text { Tabel 3.6. Model Summary Model 1- } \\
\text { Sub-Struktur } 1 \mathrm{X}_{1} \text { dan } \mathrm{X}_{2} \text { terhadap } \mathrm{Y}\end{array}$} \\
\hline \multicolumn{10}{|c|}{ Model Summary' } \\
\hline \multirow[b]{2}{*}{ Model } & \multirow[b]{2}{*}{$R$} & \multirow[b]{2}{*}{$\begin{array}{c}R \\
\text { Square }\end{array}$} & \multirow[b]{2}{*}{$\begin{array}{l}\text { Ad- } \\
\text { justed R } \\
\text { Square }\end{array}$} & \multirow[b]{2}{*}{$\begin{array}{l}\text { Std. Error } \\
\text { of the } \\
\text { Estimate }\end{array}$} & \multicolumn{5}{|c|}{ Change Statistics } \\
\hline & & & & & $\begin{array}{c}R \\
\text { Square } \\
\text { Change }\end{array}$ & FChange & df1 & df2 & $\begin{array}{l}\text { Sig. F } \\
\text { Change }\end{array}$ \\
\hline 1 & $.414^{2}$ & .172 & .162 & 4.520 & .172 & 18.028 & 2 & 174 & .000 \\
\hline \multicolumn{10}{|c|}{$\begin{array}{l}\text { a. Predictors: (Constant), Lingkungan Kerja, Tunjangan Kinerja } \\
\text { b. Dependent Variable: Motivasi Kerja }\end{array}$} \\
\hline
\end{tabular}

a. Memaknai Analisis jalur Sub-Struktur 1

Pengujian Secara Simultan (Keseluruhan), pengujian secara individual bisa dilakukan. Pengujian Secara Individual Sub-Struktur 1. Tunjangan Kinerja Berkontribusi Secara Signifikan terhadap Motivasi Kerja, tunjangan kinerja berpengaruh terhadap motivasi kerja. Lingkungan Kerja Berkontibusi Secara Signifikan terhadap Motivasi Kerja, lingkungan kerja berpengaruh terhadap motivasi kerja.

Berdasarkan hasil analisis pada tabel 4.24 diperoleh nilai koefisien jalur $: \mathrm{P}_{\mathrm{yx} 1}=$ Beta $=0,262(\mathrm{t}=3,565$ dan probabilitas (sig) $=0,000) . \mathrm{P}_{\mathrm{yx} 2}=$ Beta $=0,244(\mathrm{t}=3,315$ dan probabilitas $(\mathrm{sig})=0,001$. Dengan koefisien detrminan atau pengaruh $\left(\mathrm{R}_{\text {square }}=\mathrm{R}^{2}{ }_{\mathrm{y} \times 1 \times 2}\right)$ $=0,172$ dan besar koefisien residu $\mathrm{p}_{\mathrm{y}} \varepsilon_{1}=\sqrt{ } 1$ $0,172=\sqrt{ } 0,828=0,910$. Dengan demikian di dapat diagram jalur sub-struktur 1 sebagai berikut :

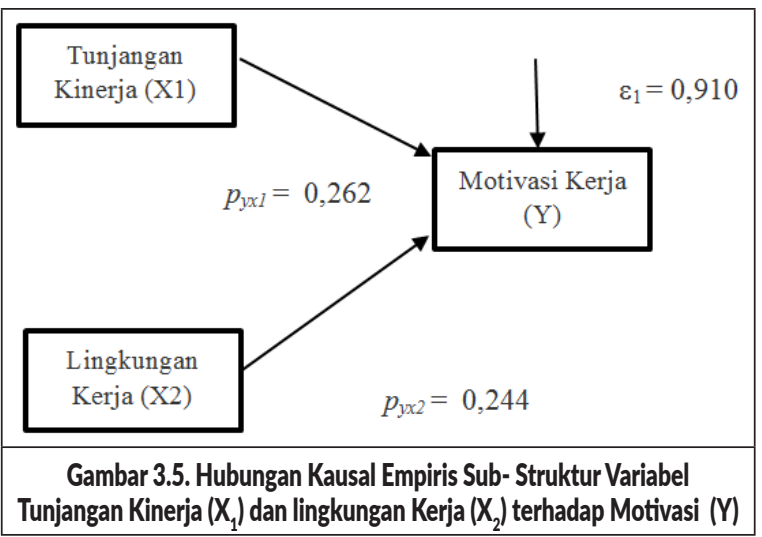

b. Menguji Sub-Struktur 2

$$
\mathrm{Z}=\mathrm{p}_{\mathrm{zx} 1} \mathrm{X}_{1}+\mathrm{p}_{\mathrm{zx} 2} \mathrm{X}_{2}+\mathrm{p}_{\mathrm{zy}} \mathrm{Y}+\mathrm{p}_{\mathrm{z}} \varepsilon_{1}
$$

Tabel 3.7. Anova Model 1-

Sub-Struktur $2 \mathrm{X}_{1}, \mathrm{X}_{2}$ dan $\mathrm{Y}$ terhadap $\mathrm{Z}$

\begin{tabular}{|c|l|r|r|r|r|r|}
\hline \multicolumn{2}{|l|}{ Model } & $\begin{array}{c}\text { Sum of } \\
\text { Squares }\end{array}$ & df & $\begin{array}{c}\text { Mean } \\
\text { Square }\end{array}$ & F & Sig. \\
\hline 1 & Regression & 4002.049 & 3 & 1334.016 & 77.818 & $.000^{\text {b }}$ \\
\hline & Residual & 2965.691 & 173 & 17.143 & & \\
\hline & Total & 6967.740 & 176 & & & \\
\hline $\begin{array}{l}\text { a. Dependent Variable: Kinerja } \\
\text { b. Predictors: (Constant), Motivasi Kerja, Lingkungan Kerja, Tunjangan Kinerja }\end{array}$ \\
\hline \multicolumn{7}{|l|}{ Sumber: Hasil output SPSS data primer yang diolah, September 2016 } \\
\hline
\end{tabular}

Tabel 3.8. Coefficients Model 1-

Sub-Struktur $2 \mathrm{X}_{1}, \mathrm{X}_{2}$ dan $\mathrm{Y}$ terhadap $\mathrm{Z}$

\begin{tabular}{|l|r|r|r|r|r|}
\hline \multirow{2}{*}{ Model } & \multicolumn{2}{|c|}{$\begin{array}{c}\text { Unstandardized } \\
\text { Coefficients }\end{array}$} & \multicolumn{2}{|c|}{ Standardized Coefficients } \\
\hline & \multicolumn{1}{c|}{ B } & \multicolumn{1}{c|}{ Std. Error } & \multicolumn{1}{c|}{ Beta } & \multicolumn{1}{c|}{$\mathrm{t}$} & \multicolumn{1}{c|}{ Sig. } \\
\hline 1 (Constant) & 7.186 & 3.417 & & 2.103 & .037 \\
\hline Tunjangan Kinerja & .144 & .039 & .201 & 3.683 & .000 \\
\hline Lingkungan Kerja & .076 & .047 & .089 & 1.638 & .103 \\
\hline Motivasi Kerja & .795 & .069 & .624 & 11.451 & .000 \\
\hline a. Dependent Variable: Kinerja & & & \\
\hline \multicolumn{7}{|c|}{ Sumber: Hasil output SPSS data primer yang diolah, September 2016} \\
\hline
\end{tabular}

Tabel 3.9. Model Summary Model 1-

Sub-Struktur $2 \mathrm{X}_{1}, \mathrm{X}_{2}$ dan $\mathrm{Y}$ terhadap Z

\begin{tabular}{|c|c|c|c|c|c|c|c|c|c|}
\hline \multirow[b]{3}{*}{ Model } & \multicolumn{9}{|c|}{ Model Summary ${ }^{b}$} \\
\hline & \multirow[b]{2}{*}{$\mathrm{R}$} & \multirow[b]{2}{*}{$\begin{array}{c}R \\
\text { Square }\end{array}$} & \multirow[b]{2}{*}{$\begin{array}{l}\text { Ad- } \\
\text { justed R } \\
\text { Square }\end{array}$} & \multirow[b]{2}{*}{$\begin{array}{l}\text { Std. Error } \\
\text { of the } \\
\text { Estimate }\end{array}$} & \multicolumn{5}{|c|}{ Change Statistics } \\
\hline & & & & & $\begin{array}{c}R \\
\text { Square } \\
\text { Change }\end{array}$ & FChange & df1 & df2 & $\begin{array}{l}\text { Sig. F } \\
\text { Change }\end{array}$ \\
\hline 1 & $.758^{\circ}$ & .574 & .567 & 4.140 & .574 & 77.818 & 3 & 173 & .000 \\
\hline \multicolumn{10}{|c|}{$\begin{array}{l}\text { a. Predictors: (Constant), Motivasi Kerja, Lingkungan Kerja, Tunjangan Kinerja } \\
\text { b. Dependent Variable: Kinerja }\end{array}$} \\
\hline
\end{tabular}

c. Memaknai Analisis Jalur Sub-Struktur 2

Pengujian Secara Simultan (Keseluruhan), tunjangan kinerja berpengaruh terhadap kinerja. Pengujian secara Individual. Lingkungan Kerja Berkontibusi Secara Signifikan terhadap Kinerja, lingkungan kerja tidak berpengaruh terhadap kinerja. Motivasi Kerja Berkontibusi Secara Signifikan terhadap Kinerja, motivasi kerja berpengaruh terhadap kinerja

Hasil analisis membuktikan bahwa ada koefisien jalur yang tidak signifikan yaitu variabel lingkungan kerja $\left(\mathrm{X}_{2}\right)$, maka Model 1 perlu diperbaiki melalui merode trimming. Hasil perhitungan sebagi berikut: 


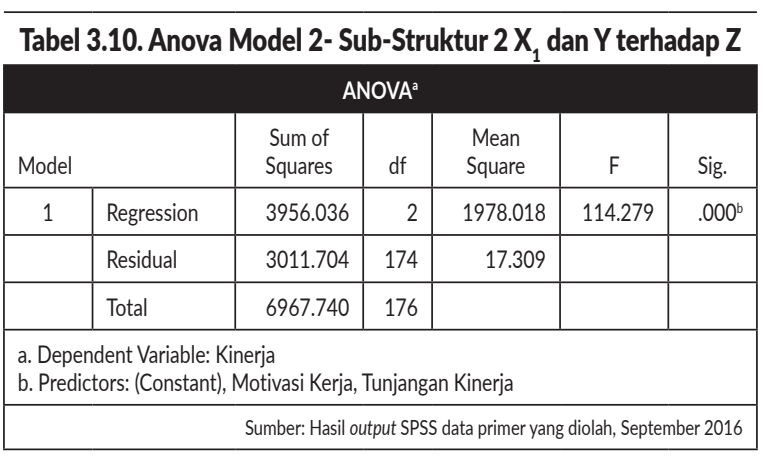

\begin{tabular}{|c|c|c|c|c|c|}
\hline \multicolumn{6}{|c|}{$\begin{array}{r}\text { Tabel 3.11. Coefficients Model 2-Sub-Str } \\
\text { Coefficients }^{a}\end{array}$} \\
\hline \multirow[t]{2}{*}{+2} & \multicolumn{2}{|c|}{$\begin{array}{l}\text { Unstandardized } \\
\text { Coefficients }\end{array}$} & \multicolumn{3}{|c|}{ Standardized Coefficients } \\
\hline & B & Std. Error & Beta & $\mathrm{t}$ & Sig. \\
\hline 1 (Constant) & 9.296 & 3.180 & & 2.923 & .004 \\
\hline Tunjangan Kinerja & .161 & .038 & .225 & 4.229 & .000 \\
\hline Motivasi Kerja & .823 & .068 & .646 & 12.161 & .000 \\
\hline \multicolumn{6}{|c|}{ a. Dependent Variable: Kinerja } \\
\hline & Sumber: $\mathrm{t}$ & sil output SP & rimer yc & lah, Se & er 2016 \\
\hline
\end{tabular}

Tabel 3.12. Model Summary Model 2-Sub-Struktur $\mathrm{X}_{1}$ dan $\mathrm{Y}$ terhadap Z

\begin{tabular}{|c|c|c|c|c|c|c|c|c|c|}
\hline \multirow[b]{3}{*}{ Model } & \multicolumn{9}{|c|}{ Model Summary } \\
\hline & \multirow[b]{2}{*}{$R$} & \multirow[b]{2}{*}{$\begin{array}{c}R \\
\text { Square }\end{array}$} & \multirow[b]{2}{*}{$\begin{array}{l}\text { Ad- } \\
\text { justed R } \\
\text { Square }\end{array}$} & \multirow[b]{2}{*}{$\begin{array}{l}\text { Std. Error } \\
\text { of the } \\
\text { Estimate }\end{array}$} & \multicolumn{5}{|c|}{ Change Statistics } \\
\hline & & & & & $\begin{array}{c}R \\
\text { Square } \\
\text { Change }\end{array}$ & FChange & df1 & $\mathrm{df} 2$ & $\begin{array}{l}\text { Sig. F } \\
\text { Change }\end{array}$ \\
\hline 1 & $.754^{\circ}$ & .568 & .563 & 4.160 & .568 & 114.279 & 2 & 174 & .000 \\
\hline \multicolumn{10}{|c|}{$\begin{array}{l}\text { a. Predictors: (Constant), Motivasi Kerja, Tunjangan Kinerja } \\
\text { b. Dependent Variable: Kinerja }\end{array}$} \\
\hline \multicolumn{10}{|c|}{ Sumber: Hasil output SPSS data primer yang diolah, September 2016} \\
\hline
\end{tabular}

\begin{tabular}{|c|c|c|c|c|c|c|}
\hline \multicolumn{7}{|c|}{$\begin{array}{c}\text { Tabel 3.13 Rangkuman Anova } \\
\text { Model } 1 \text { dan 2- Sub-Struktur } 2 \mathrm{X}_{1}, \mathrm{X}_{2} \text { dan } \mathrm{Y} \text { Terhadap Z }\end{array}$} \\
\hline \multicolumn{7}{|c|}{ ANOVA $^{2}$} \\
\hline \multicolumn{2}{|c|}{ Model } & $\begin{array}{l}\text { Sum of } \\
\text { Squares }\end{array}$ & $\mathrm{df}$ & $\begin{array}{l}\text { Mean } \\
\text { Square }\end{array}$ & $\mathrm{F}$ & Sig. \\
\hline \multirow{3}{*}{1} & Regression & 4002.049 & 3 & 1334.016 & 77.818 & $.000^{\mathrm{b}}$ \\
\hline & Residual & 2965.691 & 173 & 17.143 & & \\
\hline & Total & 6967.74 & 176 & & & \\
\hline \multirow{3}{*}{1} & Regression & 3956.036 & 2 & 1978.018 & 114.279 & $.000^{\mathrm{b}}$ \\
\hline & Residual & 3011.704 & 174 & 17.309 & & \\
\hline & Total & 6967.74 & 176 & & & \\
\hline \multicolumn{7}{|c|}{$\begin{array}{l}\text { a. Dependent Variable: Kinerja } \\
\text { b. Predictors: (Constant), Motivasi Kerja, Lingkungan Kerja, Tunjangan Kinerja }\end{array}$} \\
\hline \multicolumn{7}{|c|}{ Sumber: Hasil output SPSS data primer yang diolah, September 2016} \\
\hline
\end{tabular}

\begin{tabular}{|c|c|c|c|c|c|}
\hline \multicolumn{6}{|c|}{$\begin{array}{l}\text { Tabel 3.14. Rangkuman Coefficients Model } 1 \text { dan 2- } \\
\text { Sub- Struktur } 2 X_{1}, X_{2} \text { dan } Y \text { Terhadap } Z\end{array}$} \\
\hline \multicolumn{6}{|c|}{ Coefficients $^{\mathrm{a}}$} \\
\hline \multirow[b]{2}{*}{ Model } & \multicolumn{2}{|c|}{$\begin{array}{l}\text { Unstandardized } \\
\text { Coefficients }\end{array}$} & \multicolumn{3}{|c|}{ Standardized Coefficients } \\
\hline & B & Std. Error & Beta & $\mathrm{t}$ & Sig. \\
\hline 1 (Constant) & 7.186 & 3.417 & & 2.103 & 0.037 \\
\hline Tunjangan Kinerja & 0.144 & 0.039 & 0.201 & 3.683 & 0 \\
\hline
\end{tabular}

\begin{tabular}{|c|r|r|r|r|r|}
\hline Lingkungan Kerja & 0.076 & 0.047 & 0.089 & 1.638 & 0.103 \\
\hline Motivasi Kerja & 0.795 & 0.069 & 0.624 & 11.451 & 0 \\
\hline 2 (Constant) & 9.296 & 3.18 & & 2.923 & 0.004 \\
\hline Tunjangan Kinerja & 0.161 & 0.038 & 0.225 & 4.229 & 0 \\
\hline Motivasi Kerja & 0.823 & 0.068 & 0.646 & 12.161 & 0 \\
\hline a. Dependent Variable: Kinerja \\
\hline \multicolumn{7}{|c|}{ Sumber: Hasil output SPsS data primer yang diolah, September 2016 } \\
\hline
\end{tabular}

\begin{tabular}{|c|c|c|c|c|c|c|c|c|c|}
\hline \multicolumn{10}{|c|}{$\begin{array}{l}\text { Tabel 3.15 Rangkuman Model Summary Model } 1 \text { dan 2- } \\
\text { Sub-Struktur } \mathrm{X}_{1}, \mathrm{X}_{2} \text { dan Y Terhadap Z }\end{array}$} \\
\hline \multicolumn{10}{|c|}{ Model Summary ${ }^{b}$} \\
\hline \multirow[b]{2}{*}{ Model } & \multirow[b]{2}{*}{$\mathrm{R}$} & \multirow[b]{2}{*}{$\underset{\text { Square }}{R}$} & \multirow[b]{2}{*}{$\begin{array}{l}\text { Ad- } \\
\text { justed R } \\
\text { Square }\end{array}$} & \multirow[b]{2}{*}{$\begin{array}{l}\text { Std. Error } \\
\text { of the } \\
\text { Estimate }\end{array}$} & \multicolumn{5}{|c|}{ Change Statistics } \\
\hline & & & & & $\begin{array}{c}R \\
\text { Square } \\
\text { Change }\end{array}$ & FChange & df1 & $\mathrm{d}+2$ & $\begin{array}{l}\text { Sig. F } \\
\text { Change }\end{array}$ \\
\hline 1 & $.758^{\mathrm{a}}$ & 0.574 & 0.567 & 4.14 & 0.574 & 77.818 & 3 & 173 & c \\
\hline 2 & $.754^{a}$ & 0.568 & 0.563 & 4.16 & 0.568 & 114.279 & 2 & 174 & c \\
\hline \multicolumn{10}{|c|}{$\begin{array}{l}\text { a. Predictors: (Constant), Motivasi Kerja, Lingkungan Kerja, Tunjangan Kinerja } \\
\text { b. Dependent Variable: Kinerja }\end{array}$} \\
\hline \multicolumn{10}{|c|}{ Sumber: Hasil output SPSS data primer yang diolah, September 201} \\
\hline
\end{tabular}

\begin{tabular}{|c|c|c|c|c|c|}
\hline \multicolumn{6}{|c|}{ Tabel 3.16. Rangkuman Hasil Korelasi } \\
\hline \multicolumn{6}{|c|}{ Coefficients $^{a}$} \\
\hline & & $\begin{array}{c}\text { Tunjangan } \\
\text { Kinerja }\end{array}$ & $\begin{array}{l}\text { Lingkungan } \\
\text { Kerja }\end{array}$ & $\begin{array}{l}\text { Motivasi } \\
\text { Kerja }\end{array}$ & Kinerja \\
\hline \multirow{3}{*}{$\begin{array}{l}\text { Tunjangan } \\
\text { Kinerja }\end{array}$} & $\begin{array}{l}\text { Pearson } \\
\text { Correlation }\end{array}$ & 1 & $.343^{* *}$ & $.345^{* *}$ & $.448^{* *}$ \\
\hline & Sig. (2-tailed) & & .000 & .000 & .000 \\
\hline & $\mathrm{N}$ & 177 & 177 & 177 & 177 \\
\hline \multirow{3}{*}{$\begin{array}{l}\text { Lingkungan } \\
\text { Kerja }\end{array}$} & $\begin{array}{l}\text { Pearson } \\
\text { Correlation }\end{array}$ & $.343^{* *}$ & 1 & $.333^{* *}$ & $.366^{* *}$ \\
\hline & Sig. (2-tailed) & .000 & & .000 & .000 \\
\hline & $\mathrm{N}$ & 177 & 177 & 177 & 177 \\
\hline \multirow{3}{*}{$\begin{array}{l}\text { Motivasi } \\
\text { Kerja }\end{array}$} & $\begin{array}{l}\text { Pearson } \\
\text { Correlation }\end{array}$ & $.345^{* *}$ & $.333^{* *}$ & 1 & $.723^{* *}$ \\
\hline & Sig. (2-tailed) & .000 & .000 & & .000 \\
\hline & $\mathrm{N}$ & 177 & 177 & 177 & 177 \\
\hline \multirow{3}{*}{ Kinerja } & $\begin{array}{l}\text { Pearson } \\
\text { Correlation }\end{array}$ & $.448^{* *}$ & $.366^{* *}$ & $.723^{* *}$ & 1 \\
\hline & Sig. (2-tailed) & .000 & .000 & .000 & \\
\hline & $\mathrm{N}$ & 177 & 177 & 177 & 177 \\
\hline \multicolumn{6}{|c|}{${ }^{* *}$. Correlation is significant at the 0.01 level (2-tailed). } \\
\hline & & : Hasil output S & SSS data primer y & g diolah, Sept & nber 2016 \\
\hline
\end{tabular}

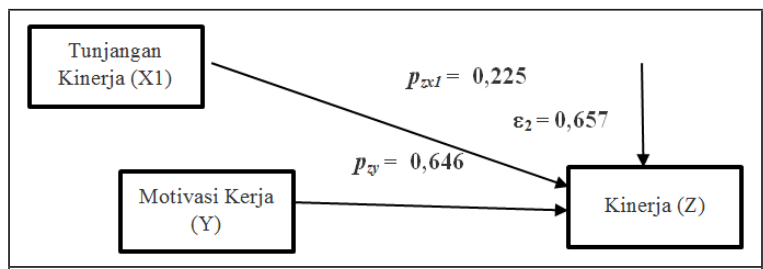

Gambar 3.6. Hubungan Kausal empiris Sub-Struktur 2 Variabel Tunjangan Kinerja $\left(\mathrm{X}_{1}\right)$ dan Motivasi Kerja ( $\mathrm{Y}$ ) terhadap Kinerja (Z) 


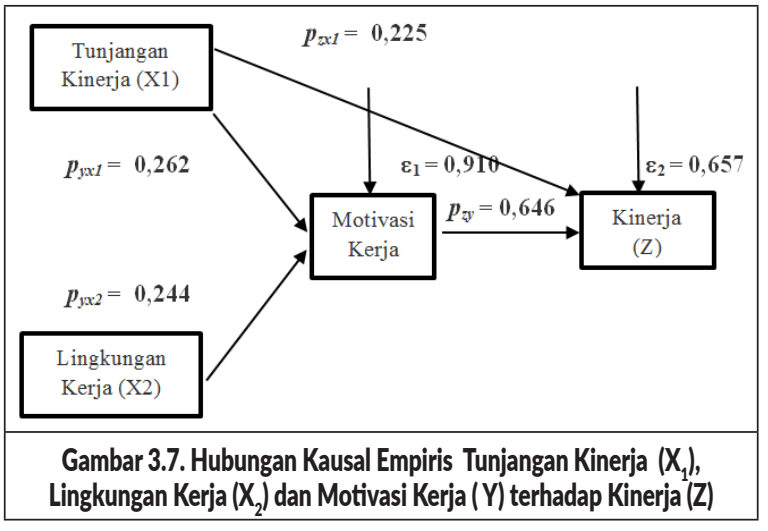

Hasil dari koefisien halur sub-struktur 1 dan sub-struktur 2 berubah menjadi persamaan struktur yaitu :

$\mathrm{Y}=\mathrm{p}_{\mathrm{yx} 1} \mathrm{X}_{1}+\mathrm{p}_{\mathrm{yx} 2} \mathrm{X}_{2}+\mathrm{p}_{\mathrm{y}} \varepsilon_{1}$ dan $\mathrm{R}^{2}{ }_{\mathrm{yx} 1 \mathrm{x} 2}$ $=0,262 \mathrm{X}_{1}+0,244 \mathrm{X}_{2}+0,910 \varepsilon_{1}$ dan $\mathrm{R}_{\mathrm{yx1 \times 2}}^{2}=$ 0,172

$\mathrm{Z}=\mathrm{p}_{z \mathrm{zx}} \mathrm{X}_{1}+\mathrm{p}_{z \mathrm{y}} \mathrm{Y}+\mathrm{p}_{\mathrm{z}} \varepsilon_{1}$ dan $\mathrm{R}^{2}{ }_{\text {zyx } 1}$ $=0,225 \mathrm{X}_{1}+0,646 \mathrm{Y}+0,657 \varepsilon_{2}$ dan $\mathrm{R}^{2}{ }_{\text {zyx1 }}=$ 0,568

d. Pengujian Kesesuaian Model Koefisien Q

Dicari dari tabel distribusi $\left(\chi^{2}\right)$ atau chi-kuadrat/chi-square untuk $\mathrm{dk}=1$ dengan $\alpha=0,05$ diperoleh sebesar 3,84146 ternyata $\mathrm{W}_{\text {hitung }}>\chi^{2}(1 ; 0,05)$ atau $35,552>3,84146$ maka Ho ditolak (artinya matriks korelasi sampel berbeda dengan matriks korelasi estimasi), maksudnya kedua model signifikan. Kesimpulan model empiris yang diperoleh melalui kemampuan mengeneralisasikan tentang fenomena yaitu variabel motivasi kerja (Y) dan prestasi kerja ( $\mathrm{Z}$ ) dengan baik

e. Memaknai Hasil Analisis Jalur

\begin{tabular}{|c|c|c|c|c|c|}
\hline $\begin{array}{r}\text { Tabel } 4.1 \\
\text { dan Penge } \\
\text { (Y) B }\end{array}$ & $\begin{array}{l}\text { Koefisie } \\
\text { uh Bersa } \\
\text { rpengaru }\end{array}$ & $\begin{array}{l}\text { Jalur, Pengar } \\
\text { a Tunjangan } \\
\text { Secara Signi }\end{array}$ & $\begin{array}{l}\text { n Langsun } \\
\text { nerja }\left(X_{1}\right) \\
\text { can terhad }\end{array}$ & $\begin{array}{l}\text { Peng } \\
\text { an Mo } \\
\text { p Kine }\end{array}$ & $\begin{array}{l}\text { in Total } \\
\text { asi kerja } \\
\text { (Z) }\end{array}$ \\
\hline & & & ggaruh & & \\
\hline Variabel & $\begin{array}{l}\text { Koefisien } \\
\text { jalur }\end{array}$ & Langsung & $\begin{array}{c}\text { Tidak } \\
\text { Langsung } \\
\text { (melalui Y) }\end{array}$ & Total & $\begin{array}{l}\text { Pengaruh } \\
\text { Bersama } \\
\mathbf{R}^{2}{ }_{27 x}\end{array}$ \\
\hline$x_{1}$ & 0,262 & & 0,646 & 0,169 & \\
\hline$X_{2}$ & 0,244 & & 0,646 & 0,158 & \\
\hline$Y$ & 0,646 & & & & \\
\hline$\varepsilon_{1}$ & 0,910 & $0,9102=0,828$ & & & \\
\hline$\varepsilon_{2}$ & 0,657 & $0,6572=0,432$ & & & \\
\hline$X_{1} \operatorname{dan} X_{2}$ & & & & & 0,172 \\
\hline$X_{1}, X_{2} \operatorname{dan} Y$ & & & & & 0,568 \\
\hline
\end{tabular}

7. Pengujian Hipotesis

a. Uji-t (Parsial)

Berdasarkan Tabel 3.5 menunjukan bahwa terdapat pengaruh yang signifikan dari tunjangan kinerja terhadap motivasi kerja.

Berdasarkan Tabel 3.5 menunjukan bahwa terdapat pengaruh yang signifikan dari lingkungan kerja terhadap motivasi kerja.

Berdasarkan Tabel 3.11 menunjukan bahwa terdapat pengaruh yang signifikan dari tunjangan kinerja terhadap kinerja.

Berdasarkan Tabel 3.8 menunjukan bahwa tidak terdapat pengaruh yang signifikan dari lingkungan kerja terhadap kinerja.

Berdasarkan Tabel 3.11 menunjukan bahwa terdapat pengaruh yang signifikan dari motivasi kerja terhadap kinerja.

b. $\quad \mathrm{Uji}_{\text {hitung }}$ (Simultan)

Berdasarkan Tabel 3.4 kedua variabel independen Tunjangan Kinerja $\left(\mathrm{X}_{1}\right)$, dan Lingkungan Kerja $\left(\mathrm{X}_{2}\right)$ berpengaruh secara simutan dan signifikan terhadap variabel dependen Motivasi Kerja (Y).

Berdasarkan Tabel 3.7 ketiga variabel independen Tunjangan Kinerja $\left(\mathrm{X}_{1}\right)$, Lingkungan Kerja $\left(\mathrm{X}_{2}\right)$ dan Motivasi Kerja (Y) berpengaruh secara simultan dan signifikan terhadap variabel dependen Kinerja $(Z)$.

c. Koefisien Determinasi $\left(\mathrm{r}^{2}\right)$

\begin{tabular}{|c|c|c|c|c|c|}
\hline \multicolumn{6}{|c|}{$\begin{array}{l}\text { Tabel 3.18. Hasil Uji Korelasi Tunjangan Kinerja, } \\
\text { Lingkungan Kerja, Motivasi Kerja, dan Kinerja }\end{array}$} \\
\hline \multicolumn{6}{|c|}{ Coefficients $^{a}$} \\
\hline & & Kinerja & $\begin{array}{c}\text { Tunjangan } \\
\text { Kinerja }\end{array}$ & $\begin{array}{l}\text { Lingkungan } \\
\text { Kerja }\end{array}$ & $\begin{array}{c}\text { Motivasi } \\
\text { Kerja }\end{array}$ \\
\hline \multirow{4}{*}{$\begin{array}{l}\text { Pearson } \\
\text { Correlation }\end{array}$} & Kinerja & 1.000 & .448 & .366 & .723 \\
\hline & $\begin{array}{l}\text { Tunjangan } \\
\text { Kinerja }\end{array}$ & .448 & 1.000 & .343 & .345 \\
\hline & $\begin{array}{l}\text { Lingkungan } \\
\text { Kerja }\end{array}$ & .366 & .343 & 1.000 & .333 \\
\hline & $\begin{array}{l}\text { Motivasi } \\
\text { Kerja }\end{array}$ & .723 & .345 & .333 & 1.000 \\
\hline \multirow{4}{*}{ Sig. (1-tailed) } & Kinerja & & .000 & .000 & .000 \\
\hline & $\begin{array}{l}\text { Tunjangan } \\
\text { Kinerja }\end{array}$ & .000 & . & .000 & .000 \\
\hline & $\begin{array}{l}\text { Lingkungan } \\
\text { Kerja }\end{array}$ & .000 & .000 & & .000 \\
\hline & $\begin{array}{l}\text { Motivasi } \\
\text { Kerja }\end{array}$ & .000 & .000 & .000 & \\
\hline \multirow[b]{2}{*}{$N$} & Kinerja & 177 & 177 & 177 & 177 \\
\hline & $\begin{array}{l}\text { Tunjangan } \\
\text { Kinerja }\end{array}$ & 177 & 177 & 177 & 177 \\
\hline
\end{tabular}




\begin{tabular}{|l|l|r|r|r|r|}
\hline & $\begin{array}{l}\text { Lingkungan } \\
\text { Kerja }\end{array}$ & 177 & 177 & 177 & 177 \\
\cline { 2 - 6 } & $\begin{array}{l}\text { Motivasi } \\
\text { Kerja }\end{array}$ & 177 & 177 & 177 & 177 \\
\hline \multicolumn{6}{|c|}{ Sumber: Hasil output SPSS data primer yang diolah, September 2016 } \\
\hline
\end{tabular}

Dari Tabel 4.6 diketahui nilai koefisien $\mathrm{R}$ sebesar 0,414, dapat diartikan bahwa hubungan antar variabel mempunyai hubungan yang sedang. Sumbangan tunjangan kinerja dan lingkungan kerja terhadap motivasi kerja adalah ditentukan dengan rumus koefisien determinasi $(\mathrm{KD})=17,2 \%$

Dari Tabel 4.6 di atas diketahui nilai koefisien R sebesar 0,345, dapat diartikan bahwa hubungan antaar variabel mempunyai hubungan yang rendah. Sumbangan Tunjangan Kinerja terhadap motivasi kerja adalah ditentukan dengan rumus koefisien determinasi $(\mathrm{KD})=6,86 \%$.

Pengaruh Lingkungan Kerja Terhadap Motivasi Kerja. Dari Tabel 4.6 di atas diketahui nilai koefisien $\mathrm{R}$ sebesar 0,333, dapat diartikan bahwa hubungan antara variabel mempunyai hubungan yang rendah. Sumbangan lingkungan kerja terhadap motivasi kerja adalah ditentukan dengan rumus koefisien determinasi $(\mathrm{KD})=5,95$ $\%$.

Pengaruh Tunjangan Kinerja, Lingkungan Kerja dan Motivasi Kerja Terhadap Kinerja. Dari Tabel 4.9 di atas diketahui nilai koefisien $\mathrm{R}$ sebesar 0,758, dapat diartikan bahwa hubungan antara mempunyai hubungan yang kuat. Sumbangan tunjangan kinerja dan lingkungan kerja terhadap motivasi kerja adalah ditentukan dengan rumus koefisien determinasi $(\mathrm{KD})=57,4 \%$.

Pengaruh Tunjangan Kinerja Terhadap kinerja. Dari Tabel 4.12 di atas diketahui nilai koefisien $\mathrm{R}$ sebesar 0,448, dapat diartikan bahwa hubungan antara mempunyai hubungan yang sedang. Sumbangan tunjangan kinerja terhadap kinerja adalah ditentukan dengan rumus koefisien determinasi $(\mathrm{KD})=5,06 \%$.

Pengaruh tidak langsung tunjangan kinerja $\left(\mathrm{X}_{1}\right)$ terhadap kinerja $(\mathrm{Z})$ melalui motivasi kerja (Y) sebesar $\mathrm{p}_{\mathrm{zx} 1} \cdot \mathrm{p}_{\mathrm{zy}}=0,262 \cdot 0,646=0,169$. Dengan demikian pengaruh total $\mathrm{X}_{1}$ terhadap $\mathrm{Z}$ sebesar $0,169=16,9 \%$.

Pengaruh Lingkungan Kerja Terhadap ki- nerja. Dari Tabel 4.9 di atas diketahui nilai koefisien $\mathrm{R}$ sebesar 0,336, dapat diartikan bahwa hubungan antara mempunyai hubungan yang rendah.Sumbangan lingkungan kerja terhadap kinerja adalah 0,158 . Dengan demikian pengaruh total sebesar $0,158=15,8 \%$

Pengaruh tidak langsung lingkungan kerja $\left(\mathrm{X}_{2}\right)$ terhadap kinerja $(\mathrm{Z})$ melalui motivasi kerja (Y) sebesar 0,158. Dengan demikian pengaruh total $\mathrm{X}_{2}$ terhadap Z sebesar 0,158 $=15,8 \%$

Pengaruh Motivasi Kerja Terhadap Kinerja. Dari Tabel 4.12 di atas diketahui nilai koefisien $\mathrm{R}$ sebesar 0,723, antar variabel mempunyai hubungan yang kuat.Sumbangan tunjangan kinerja dan lingkungan kerja terhadap motivasi kerja adalah ditentukan dengan rumus koefisien determinasi $(\mathrm{KD})=41,73 \%$. Maknanya sumbangan $41,73 \%$.

\section{Pembahasan}

Secara rinci, pengaruh antara masing-masing variabel adalah sebagai berikut

1. Pengaruh Tunjangan Kinerja dan Lingkungan Kerja Terhadap Motivasi Kerja.

Berdasarkan uji hipotesis bahwa $\mathrm{F}_{\text {hitung }}>$ $\mathrm{F}_{\text {tabel }}=(18,028>3,05)$. Diperoleh pula nilai probabilitas Sig. adalah sebesar 0,000 lebih kecil dari nilai probabilitas $0,05(0,000<$ $0,05)$, maka Ho ditolak dan Ha diterima yang artinya tunjangan kinerja dan lingkungan kerja berpengaruh secara signifikan terhadap motivasi kerja. Dari hasil uji pula diketahui bahwa secara simultan, tunjangan kinerja dan lingkungan kerja memberikan sumbangan pengaruh sebesar $17,2 \%$ terhadap motivasi kerja.

Hasil uji tersebut sesuai dengan penelitian terdahuu yang telah dilakukan dan sesuai pula dengan teori dari Permenhut Nomor :P.34/Menhut-II/2014 Tentang tata Cara Pemberian Tunjangan Kinerja Bagi pegawai di Lingkungan Kementerian kehutanan. Dengan adanya tunjangan kinerja yang memadai dan lingkungan kerja yang ergonimis sehingga terbentuk kondisi yang EASNE yaitu efektif, aman, sehat, nyaman dan efisien, maka diharapkan agar per- 
gerakan, arahan, dan kegigihan dari sikap sukarela pegawai mengarah pada tujuan organisasi.

2. Pengaruh Tunjangan Kinerja Terhadap Motivasi Kerja .

Berdasarkan uji hipotesis diperoleh nilai $\mathrm{t}_{\text {hitung }}>\mathrm{t}_{\text {tabel }}=(3,565>1,97361)$, dan nilai probabilitas Sig. adalah sebesar 0,000 lebih kecil dari nilai probabilitas $0,05(0,000$ $<0,05$ maka Ho ditolak dan Ha diterima yang artinya tunjangan kinerja berpengaruh secara signifikan terhadap tunjangan kinerja. Diketahui pula bahwa tunjangan kinerja memberikan sumbangan pengaruh sebesar $6,86 \%$ terhadap motivasi kerja.

Hal ini sesuai dengan hasil penelitian terdahulu dimana tunjangan kinerja memberikan pengaruh yang signifikan terhadap motivasi kerja. Juga sesuai dengan pengertian tunjangan kinerja dalam Permenhut Nomor :P.34/Menhut-II/2014 Semakin baik dan tinggi besaran tunjangan kinerja pada Ditjen PHPL Kemen LHK maka semakin baik dan tinggi pula pergerakan, arahan, dan kegigihan dari sikap sukarela pegawai yang mengarah pada tujuan organisasi pegawai dalam rangka mencapai target dan tujuan yang telah ditentukan.

3. Pengaruh Lingkungan Kerja Terhadap Motivasi Kerja.

Berdasarkan kepada hasil uji hipotesis yang telah dilakukan diperoleh nilai $\mathrm{t}_{\text {hitung }}>$ $\mathrm{t}_{\text {tabel }}=(3,315>1,97361)$, nilai probabilitas Sig. adalah sebesar 0,001 lebih kecil dari nilai probabilitas $0,05(0,001<0,05)$, maka Ho ditolak dan Ha diterima yang artinya lingkungan kerja berpengaruh secara signifikan terhadap motivasi kerja. Dari hasil diatas pula diketahui pula bahwa lingkungan kerja memberikan sumbangan 5,95\% terhadap motivasi kerja.

Hasil tersebut sesuai dengan hasil penelitian terdahulu yang telah dilakukan dimana lingkungan kerja berpengaruh positif dan signifikan terhadap motivasi kerja. Serta sesuai dengan teori yang disampaikan oleh Sedarmayanti. Dengan lingkungan kerja yang baik dan kondusif maka pegawai akan senang serta bersemangat sehingga pergerakan, arahan, dan kegigihan dari sikap sukarela pegawai mengarah pada tujuan organisasi untuk melaksanakan tugas-tugasnya. Lingkungan kerja yang baik akan sangat menentukan keberhasilan pencapaian tujuan organisasi.

4. Pengaruh Tunjangan Kinerja, Lingkungan Kerja, dan Motivasi Kerja Terhadap Kinerja

Berdasarkan uji hipotesis bahwa $\mathrm{F}_{\text {hitung }}>$ $\mathrm{F}_{\text {tabel }}=(77,818>2,66)$. Diperoleh pula nilai probabilitas Sig. adalah sebesar 0,000 lebih kecil dari nilai probabilitas $0,05 \quad(0,000<$ 0,05), maka Ho ditolak dan Ha diterima yang artinya tunjangan kinerja dan lingkungan kerja berpengaruh secara simultan dan signifikan terhadap motivasi kerja. Dari hasil uji pula diketahui bahwa secara simultan, tunjangan kinerja, lingkungan kerja dan motivasi kerja memberikan sumbangan pengaruh sebesar 56,8\% terhadap kinerja.

Hal ini sesuai dengan penelitian terdahulu yang telah dilakukan, dan sesuai pula dengan teori yang disampaikan bahwa para ahli dimana Dengan adanya tunjangan kinerja yang memadai dan lingkungan kerja yang ergonimis serta dengan pergerakan, arahan, dan kegigihan dari sikap sukarela pegawai mengarah pada tujuan organisasi akan memberikan pengaruh berupa peningkatan prestasi/kemampuan kerja yang diperlihatkan oleh seorang pegawai Kementerian LHK dalam melaksanakan tugas dan fungsinya akan berjalan sesuai dengan tujuan yang diharapkan.

5. Pengaruh Tunjangan Kinerja Terhadap Kinerja

Berdasarkan uji hipotesis diperoleh nila $\mathrm{t}_{\text {hitung }}>\mathrm{t}_{\text {tabel }}=(4,229>1,97361)$, nilai probabilitas Sig. adalah sebesar 0,000 lebih kecil dari nilai probabilitas $0,05 \quad(0,000<$ $0,05)$, maka Ho ditolak dan Ha diterima yang artinya motivasi kerja berpengaruh secara signifikan terhadap kinerja. Dari hasil uji yang telah dilakukan pula diperoleh sumbangan pengaruh motivasi kerja sebesar 5,06\% 
terhadap kinerja. Pengaruh tidak langsung tunjangan kinerja $\left(\mathrm{X}_{1}\right)$ terhadap kinerja $(\mathrm{Z})$ melalui motivasi kerja $(\mathrm{Y})$ sebesar $\mathrm{p}_{\mathrm{yx} 1} \cdot \mathrm{p}_{\mathrm{zy}}$ $=0,262 \cdot 0,646=0,169$. Dengan demikian pengaruh total $\mathrm{X}_{1}$ terhadap $\mathrm{Z}$ sebesar 0,169 .

Hal ini sesuai dengan hasil penelitian terdahulu dimana tunjangan kinerja memberikan pengaruh yang signifikan terhadap kinerja. Semakin baik dan tinggi besaran tunjangan kinerja pada Ditjen PHPL Kemen LHK maka semakin baik dan tinggi pula prestasi/kemampuan kerja yang diperlihatkan oleh seorang pegawai Kementerian Kehutanan dalam melaksanakan tugas dan fungsinya. Sehingga memiliki kinerja optimal agar dapat lebih berprestasi dan membawa citra baik Kementerian Lingkungan Hidup dan Kehutanan di mata masyarakat dalam rangka mencapai target dan tujuan yang telah ditentukan.

6. Pengaruh Lingkungan Kerja Terhadap Kinerja

Berdasarkan uji hipotesis diperoleh nila $\left.\mathrm{t}_{\text {hitung }}>\mathrm{t}_{\text {tabel }}=1,638>1,97361\right)$, nilai probabilitas Sig. adalah sebesar 0,103 lebih kecil dari nilai probabilitas $0,05(0,103<$ 0,05), maka Ho diterima dan Ha ditolak yang artinya motivasi kerja tidak berkontibusi secara signifikan terhadap kinerja. Dari hasil uji yang telah dilakukan pula diperoleh sumbangan pengaruh tidak langsung lingkungan kerja sebesar 15,8\% terhadap kinerja. Pengaruh tidak langsung lingkungan kerja $\left(\mathrm{X}_{2}\right)$ terhadap kinerja $(\mathrm{Z})$ melalui motivasi kerja $(\mathrm{Y})$ sebesar $\mathrm{p}_{\mathrm{yx2}} \cdot \mathrm{p}_{\mathrm{zy}}=0,244.0,646=$ 0,158 . Dengan demikian pengaruh total $\mathrm{X}_{2}$ terhadap Z sebesar 0,158 .

Hasil tersebut tidak sesuai dengan hasil penelitian terdahulu yang telah dilakukan dimana lingkungan kerja berpengaruh positif dan signifikan terhadap kinerja. Hasil uji tersebut juga tidak sesuai dengan teori yang disampaikan oleh Sedarmayanti dimana lingkungan kerja adalah keseluruhan alat perkakas dan bahan yang dihadapi, lingkungan sekitarnya dimana seseorang bekerja, metode kerjanya, serta pengaturan kerjanya baik sebagai perseorangan maupun sebagai kelompok.

7. Pengaruh Motivasi Kerja Terhadap Kinerja

Berdasarkan uji hipotesis diperoleh nila $\mathrm{t}_{\text {hitung }}>\mathrm{t}_{\text {tabel }}=(12,161>1,97361)$, nilai probabilitas Sig. adalah sebesar 0,000 lebih kecil dari nilai probabilitas $0,05 \quad(0,000<$ 0,05), maka Ho ditolak dan Ha diterima yang artinya motivasi kerja berpengaruh secara signifikan terhadap kinerja. Dari hasil uji yang telah dilakukan pula diperoleh sumbangan pengaruh motivasi kerja sebesar $41,73 \%$ terhadap kinerja.

Hasil uji hipotesis yang telah dilakukan oleh penulis sesuai dengan hasil penelitian yang telah dilakukan sebelumnya, selain itu hasil uji ini sesuai dengan teori motivasi kerja Hal ini berarti bahwa dengan motivasi kerja yang tinggi maka akan berdampak positifpada kinerja pegawai tersebut. Maksudnya dengan motivasi kerja dan yang tinggi maka prestasi/ kemampuan kerja yang diperlihatkan oleh seorang pegawai Kementerian Kehutanan dalam melaksanakan tugas dan fungsinya akan berjalan sesuai dengan tujuan yang diharapkan.

\section{SIMPULAN}

\section{Kesimpulan}

Berdasarkan hasil analisis dan pembahasan maka dapat diambil kesimpulan :

1. Terdapat pengaruh secara simultan dan signifikan dari tunjangan kinerja dan lingkungan kerja terhadap motivasi kerja.

2. Terdapat pengaruh secara signifikan dari tunjangan kinerja terhadap motivasi kerja

3. Terdapat pengaruh secara signifikan dari lingkungan kerja terhadap motivasi kerja

4. Terdapat pengaruh secara signifikan dari tunjangan kinerja, lingkungan kerja dan motivasi kerja terhadap kinerja.

5. Terdapat pengaruh secara signifikan dari tunjangan kinerja terhadap kinerja.

6. Tidak terdapat pengaruh secara signifikan dari lingkungan kerja terhadap kinerja.

7. Terdapat pengaruh secara signifikan dari 
motivasi kerja terhadap kinerja

\section{Saran}

Berdasarkan hasil analisis dan kesimpulan penelitian ini maka penulis memberikan saransaran sebagai berikut :

1. Melihat hasil penelitian, tunjangan kinerja dan lingkungan kerja memberikan pengaruh yang rendah terhadap motivasi kerja sehingga perlu kiranya pejabat di lingkup Ditjen PHPL lebih memperhatikan faktorfaktor tersebut sehingga bisa meningkatkan motivasi kerja pegawai Ditjen PHPL.

2. Perlu dilakukan penelitian lanjutan terhadap variabel-variabel bebas yang mempunyai hubungan atau yang dapat mempengaruhi kinerja pegawai Ditjen PHPL.

\section{DAFTAR PUSTAKA}

Arep. Ishak dan Hendri. Tanjung, 2003, Manajemen Sumber Daya Manusia, Universitas Trisakti, Jakarta.

Dressler. Gary, 2007, Manajemen Sumber Daya Manusia Jilid 2, PT.Indeks, Jakarta. 2011, Manajemen Sumber Daya Manusia, Penerbit Indeks, Jakarta.

Fattah. Nanang, 2011, Landasan Manajemen Pendidikan, PT. Remaja Rosdakarya, Bandung.

Flippo. Edwin B, 1994, Manajemen Personalia: Edisi Keenam, jilid 1, Erlangga, Jakarta.

Ghozali, Imam. 2005. Aplikasi Analisis Multivariate dengan program SPSS. Semarang : Universitas Diponegoro. 2011, Aplikasi Analisis Multivariate dengan Program IBM SPSS 19, Cetakan Kelima. Badan Penerbit Universitas Diponegoro, Semarang.

G R Terry dan L. W. Rue, 2009, Dasar-dasar Manajemen, Bumi Aksara, Jakarta .

Handoko. Hani, 1989, Manajemen Personalia dan Sumberdaya Manusia, Edisi 2 BPFE Yogyakarta, Yogyakarta.

Hasibuan. SP Malayu, 2001, Manajemen Sumber daya Manusia : Edisi Revisi, Bumi Aksara, Jakarta.

Jaroslav. Nekoranec, 2014, Adaptation Of Employees in the Organization and its Importance in Terms of Human Resource Management, Revista Academiei Fortelor Terestre, Vol 19 issue 1. P.114-120, April 2015.

Kadarisman. M. Drs, 2012, Manajemen Kompensasi, PT. Rajagrafindo Persada, Jakarta.

2013, Manajemen Pengembangan Sumber Daya Manusia, PT. Rajagrafindo Persada, Jakarta.

Malthis, L Robert \& Jackson, H John, 2006, Human Resource Management (Terjemahan Diana Angelica), Edisi Sepuluh, Salemba Empat, Jakarta

Mangkunegara. A Anwar Prabu, 2011, Manajemen Sumber Daya Manusia Perusahaan, PT. Remaja Rosda Karya, Bandung.

Murtiyoko. Heri, 2014, Pengaruh Kompensasi dan Motivasi kerja Terhadap Kinerja karyawan (Studi kasus di PT. Lautan Otsuka Chemical), Universitas Pamulang. P. 57-97.

Musingafi. Maxwell. Zebron,. Shupikai. Chimbwanda,. Florence. Chaminuka,. Lilian, 2014, Applying the Marketing Concept to School Management in Zimbabwe, Journal of Education and Practice www.iiste.org ISSN 2222-1735 (Paper) ISSN 2222-288X (Online) Vol.5, No.39. Mei 2015.

Peraturan Pemerintah No 101 Tahun 2000 tentang Pendidikan dan Pelatihan Jabatan Pegawai Negeri Sipil.

Peraturan Pemerintah Republik Indonesia Nomor 46 Tahun 2011 Tentang Penilaian Prestasi Kerja Pegawai Negeri Sipil.

Peraturan Presiden Republik Indonesia Nomor 79 Tahun 2013 tentang Tunjangan Kinerja di Lingkungan Kementeria Kehutanan.

Peraturan Menteri Kehutanan Nomor :P.34/ Menhut-II/2014 Tentang tata Cara Pemberian Tunjangan Kinerja Bagi pegawai di Lingkungan Kementerian kehutanan.

Peraturan Menteri Lingkungan HIdup dan kehutanan Nomor : P.18/Menhut-II/2015 tentang Organisasi dan Tata Kerja Kementerian Lingkungan Hidup dan Kehutanan.

Priyatno, Duwi SE, 2016, SPSS Handbook Analisis data, Olah Data dan Penyelesaian Kasuskasus Statistik, Mediakom, Yogyakarta. 
Rachmawati. Ike Kusdyah, 2008, Manajemen Sumber Daya Manusia, Penerbit Andi, Yogyakarta.

Rachmawati. Febri, 2013, Analisis pengaruh motivasi kerja, lingkungan kerja dan disiplin karyawan terhadap kinerja karyawan (studi kasus pada PT. Alvindo Catur Sentosa), Universitas Pamulang. P.23.

Rahmawanti. Nela prima,. Swasto. Bambang,. Prasetya. Arik, 2014, Pengaruh Lingkungan Kerja terhadap Kinerja Karyawan (Studi pada Karyawan Kantor Pelayanan Pajak Pratama Malang Utara), Jurnal Administrasi Bisnis (JAB) Vol.8 No.2, P 2-3. Maret 2014

Riduwan, 2013, Metode dan Teknik Menyusun Tesis, Alfabeta, Bandung.

2014, Metode dan Teknik Menyusun Proposal Penelitian, Alfabeta, Bandung.

Riduwan. Dr. MBA dan Kuncoro. Engkos Achmad. SE. MM, 2014, Cara menggunakan dan memaknai Path Analysis (Analisis Jalur), Alfabeta, Bandung.

Salam, Rendi. 2013, Pengaruh Kompetensi dan Lingkungan Kerja terhadap Motivasi serta Dampaknya terhadap Prestasi kerja Pegawai Direktorat Pengembangan Usaha Ditjen P2MKT Kemenakertrans, Universitas Pamulang, Universitas Pamulang, P.31-32.

Seputra, Yulius Eka Agung, 2014, Manajemen dan perilaku Organisasi, Graha Ilmu, Yogyakarta.

Sedarmayanti, 2009, Sumber Daya Manusia dan Produktivitas kerja, CV. Mandar Maju, Bandung.

,2011, Tata Kerja dan Produktivitas Kerja. Suatu Tinjauan dari Aspek Ergonmi atau Kaitan antara Manusia dan Lingkungan Kerjanya, Mandar Maju, Bandung.

,2015, Manajemen Sumber Daya Manusia. Reformasi Birokrasi dan Manajemen Pegawai Negeri Sipil, PT. Refika Aditama, Bandung.

Sudjana, 2008, Metoda Statistika, Penerbit Tarsito, Bandung.

Sugiyono, Prof Dr , 2004, Metode Penelitian Bisnis, Bandung, Alfabeta. , 2010, Metode Penelitian Bisnis,

Penerbit Alfabeta, Bandung.
2011 Metode Penelitian Kuantitatif, Kualitatif dan R\&D, Alfabeta. Bandung. , 2012, Metode Penelitian Bisnis, Alfabeta, Bandung.

Sutrisno. Edy, 2009, Manajemen Sumber Daya Manusia, Edisi Pertama. Kencana Prenada Media Group, Jakarta.

Trebble. Timothy ,. Heyworth. Nicola,. Clarke. Nicholas,. Powell. Timothy,. Hockey, Peter M,. 2014. Managing hospital doctors and their practice: what can we learn about human resource management from nonhealthcare organisations, BMC Health Service Research.2014, Vol 14 issue 1, P.566-558.23p. April 2015.

Wursanto. Ig Drs, 2003, Dasar-dasar Ilmu Organisasi, Andi Yogyakarta, Yogyakarta.

Zainal. Veithzal Rivai, Ramli. Mansyur, Mutis. Thoby, dan Arafah. Wili., 2009, Manajemen Sumber Daya Menusia untuk Perusahaan dari Teori ke Praktik. Edisi ketiga, PT. RajaGrafindo Persada, Jakarta.

Arifin. Tajul, 2013, Teori dan teknik Pembuatan Desain Penelitian. (online). Tersedia:http:// www.kopertais 2.or.id/_uploads/ post/2013/07/02/20130702225327-655.pdf (Mei 2015).

Kementerian Lingkungan Hidup dan Kehutanan, Profil Kemen LHK. www.kemenlhk.go.id (September 2016)

M Priatna. Bambang Avip, 2008, Instrumen Penelitian. (online), tersedia : http://file. upi.edu/Direktori/FPMIPA/JUR._PEND._ MATEMATIKA/ 196412051990031 BAMBANG_AVIP_PRIATNA_M/Makalah_ November_2008.pdf

Resna. Riksa Wibawa, 2015, Instrumen Penelitian. (online), Tersedia : http://stikesbanten. ac.id/data/kepustakaan/INSTRUMEN\%20 PENELITIAN.pdf 